\title{
Splenic B-Cell Lymphoma/Leukemia, Unclassifiable
}

National Cancer Institute

\section{Source}

National Cancer Institute. Splenic B-Cell Lymphoma/Leukemia, Unclassifiable. NCI

Thesaurus. Code C80308.

A small B-cell clonal lymphoproliferative disorder of the spleen that does not fall into any of the other categories of mature B-cell neoplasms. 